\title{
Convalescent Plasma for the Treatment of Severe COVID-19
}

This article was published in the following Dove Press journal:

Biologics: Targets and Therapy

\section{Massimo Franchini \\ Giancarlo Maria Liumbruno (iD}

Department of Hematology and Transfusion Medicine, Carlo Poma Hospital, Mantova, Italy
Correspondence: Massimo Franchini Department of Hematology and Transfusion Medicine, Carlo Poma Hospital, Mantova, Italy

Tel +039-0376-20I 234

Fax +039-0376-220144

Email massimo.franchini@asst-mantova.it

\begin{abstract}
The COVID-19 pandemic in 2020 is one of the worst catastrophic events in human history. Several non-specific antiviral drugs have been tried to defeat the SARS-CoV-2, with mixed results. Convalescent plasma from patients who have recovered from COVID-19 is one of the specific biologic therapies being considered to treat SARS-CoV-2 infection. Preliminary studies have shown that convalescent plasma, containing antibodies able to neutralize SARS-CoV-2, is promising in blocking viral replication and improving patients' clinical symptoms. The results of several ongoing randomized controlled trials are, however, keenly awaited to definitively elucidate the safety and efficacy of this blood component in COVID-19. In this narrative review, we summarize the current evidence from the literature on the treatment of severe COVID-19 with convalescent plasma. A concise overview of the hypothesized mechanisms of action is also presented.
\end{abstract}

Keywords: SARS-CoV-2, COVID-19, hyperimmune plasma, convalescent plasma, therapy

\section{Introduction}

Coronavirus (CoV), an enveloped single-stranded RNA virus belonging to the family of Coronaviridae, which initially caused enzootic infections, has been shown in the last decades to be capable of crossing the species barrier and infecting humans. ${ }^{1,2}$ Two outbreaks of coronaviruses in humans have occurred since the beginning of the second millennium, causing Severe Acute Respiratory Syndrome (SARS-CoV) in 2002 and Middle East Respiratory Syndrome (MERS-CoV) in 2012. ${ }^{3-5}$ In December 2019, the third outbreak of a rapidly transmitted coronavirus, named SARS-CoV-2, emerged. This novel coronavirus causes a syndrome including pneumonia, which was later named Coronavirus Disease 2019 (COVID-19) by the World Health Organization (WHO). ${ }^{6}$

SARS-CoV-2 was first discovered in the city of Wuhan, China, and spread rapidly to many countries. On March, 11 2020, the WHO declared that the infection was a global pandemic. ${ }^{7}$ This new virus posed a major challenge among physicians because it had no specific pre-existing therapy. As a consequence, the therapeutic efforts were initially focused on optimizing respiratory care, managing thrombotic and inflammatory complications by using anticoagulation and corticosteroids, and repurposing existing antiviral therapies (eg, hydroxychloroquine, lopinavir/ritonavir and remdesivir). Despite anecdotal evidence, designs of clinical trials have not concluded that a statistically significant effect occurs in patient cohorts analyzed thus far. ${ }^{8-10}$ Considering the lack of effective antiSARS-CoV-2 drugs and the initial positive experience from China, ${ }^{10,11}$ convalescent plasma (CP), an old therapy used with apparent success in many epidemics and outbreaks since the 1918 Spanish flu, ${ }^{12-15}$ was proposed again also for COVID-19. 
In this narrative review, after a presentation of the most plausible mechanisms of action of $\mathrm{CP}$, we critically discuss the main literature results on the use of $\mathrm{CP}$ as a treatment for severe COVID-19.

As a search literature strategy, the Medline and PubMed electronic database was searched on this topic. The Medical Subject Heading and keywords used were: "convalescent plasma", "hyperimmune plasma", "therapy", "SARS-CoV -2", "COVID-19", "safety" and "efficacy". We also screened the reference lists of the most relevant review articles for additional studies not identified in the initial literature search.

\section{Mechanisms of Action of Convalescent Plasma}

The antiviral properties of $\mathrm{CP}$ are undoubtedly mostly due to the presence of neutralizing antibodies directed against the SARS-Cov-2 membrane spike protein, which mediates the attachment between the virus and host cell surface ACE2 receptors, facilitating viral entry into the host cell. ${ }^{1,2}$ These antibodies are therefore passively transferred through CP transfusion from recovered donors to COVID-19-affected recipients, who are not able to generate a sufficient immune response (passive immunity). Indeed, a number of studies have associated the efficacy of $\mathrm{CP}$ therapy, measured by improvement in clinical presentation and the decreased viral load, with the concentration of neutralizing antibodies in plasma from recovered donors. ${ }^{11,16}$ A similar mechanism was also observed when CP was used during the previous SARS-CoV and MERS outbreaks. ${ }^{17,18}$ In addition, other immunomodulatory actions linked to the passive antibody transfer by $\mathrm{CP}$ infusion, able to interfere with complement activation, antibodydependent cellular toxicity and phagocytosis, may help to limit the inflammatory cascade, which is well known to have often more deleterious effects than the virus itself. ${ }^{19}$ The neutralizing activity of plasma for SARS-COV2 is measured by the ability of its highest dilution to reduce $50 \%$ of viral plaques in culture compared to control plasma. The virus neutralization by plaque reduction assay is currently the gold standard method for the determination of viral neutralizing antibody titers; this test is, however, not widely available because it is labor-intensive, time-consuming (3-5 days) and requires a biosafety level 3 laboratory. To overcome these difficulties, a number of surrogate neutralization assays, utilizing ELISA or other serological test methods to measure antibody titers, have been developed. ${ }^{20}$ Although the majority of studies have demonstrated a high degree of correlation between antibody titers measured with immunoassays and virus neutralization assay, the concordance is not absolute and carries some degrees of discrepancy. ${ }^{21-23}$

Finally, a completely different pathogenic mechanism, involving the $\mathrm{ABO}$ blood group system, has been proposed recently. ${ }^{24,25}$ There is a hypothesis that people with O blood type are less susceptible to SARS-CoV-2 infection than those with non-O blood groups. ${ }^{26}$ This possible difference in susceptibility might be related to the presence of IgG anti-A isoagglutinins in O blood group subjects, which would prevent the binding of SARS-CoV-2 to its receptor thereby inhibiting the virus from entering into the targeted human cells. ${ }^{27}$

All in all, the mechanism at the basis of the clinical efficacy of CP is not completely understood and deserves further research. Nevertheless, it is reasonable that multiple mechanistic pathways may be contemporarily involved acting separately or, more probably, in a synergic way.

\section{Literature Results}

\section{Clinical Trials}

First used against SARS-CoV-2 in China ${ }^{11,28}$ and Italy, ${ }^{29}$ $\mathrm{CP}$ was rapidly deployed in many countries. ${ }^{30}$ Table 1 reports the characteristics of the main studies evaluating the safety and efficacy of CP in COVID-19 patients.

Duan and colleagues ${ }^{28}$ presented a series of ten severely ill COVID-19 patients, all of whom were given a $200 \mathrm{~mL}$ transfusion of $\mathrm{CP}$, containing high titers of neutralizing antibody $(>1: 640)$, at a median of 16.5 days after the onset of illness. The primary endpoint was safety, which was demonstrated by the fact that all patients tolerated the $\mathrm{CP}$ transfusion well and none had severe adverse events. The secondary endpoints included improvements in clinical symptoms and laboratory values from day 3 after $\mathrm{CP}$ infusion. Reported effects of the $\mathrm{CP}$ transfusion included increases in neutralizing antibody titer, oxygen saturation and lymphocyte count and decreases in C-reactive protein (CRP), SARS-CoV-2 viral load and lung lesions on chest radiograms. ${ }^{28}$

In a proof-of-concept, one-arm, multicenter, interventional study, Perotti and colleagues ${ }^{29}$ observed the effects of CP infusion in 46 severe COVID-19 patients in the short-term (7 days) period. Improvement in clinical and chest radiogram severity, laboratory values (CRP, ferritin and lactate dehydrogenase $[\mathrm{LDH}]$ ) and functional respiratory parameters (partial pressure of arterial oxygen to fraction of inspired oxygen ratio $\left.\left[\mathrm{P}_{\mathrm{AO} 2} / \mathrm{F}_{\mathrm{IO} 2}\right]\right)$ were observed at the 7-day follow-up. A significant reduction of mortality rate (from $15 \%$ to $6.5 \%$ ) was observed comparing the mortality data with those of an historical cohort group. ${ }^{29}$ 


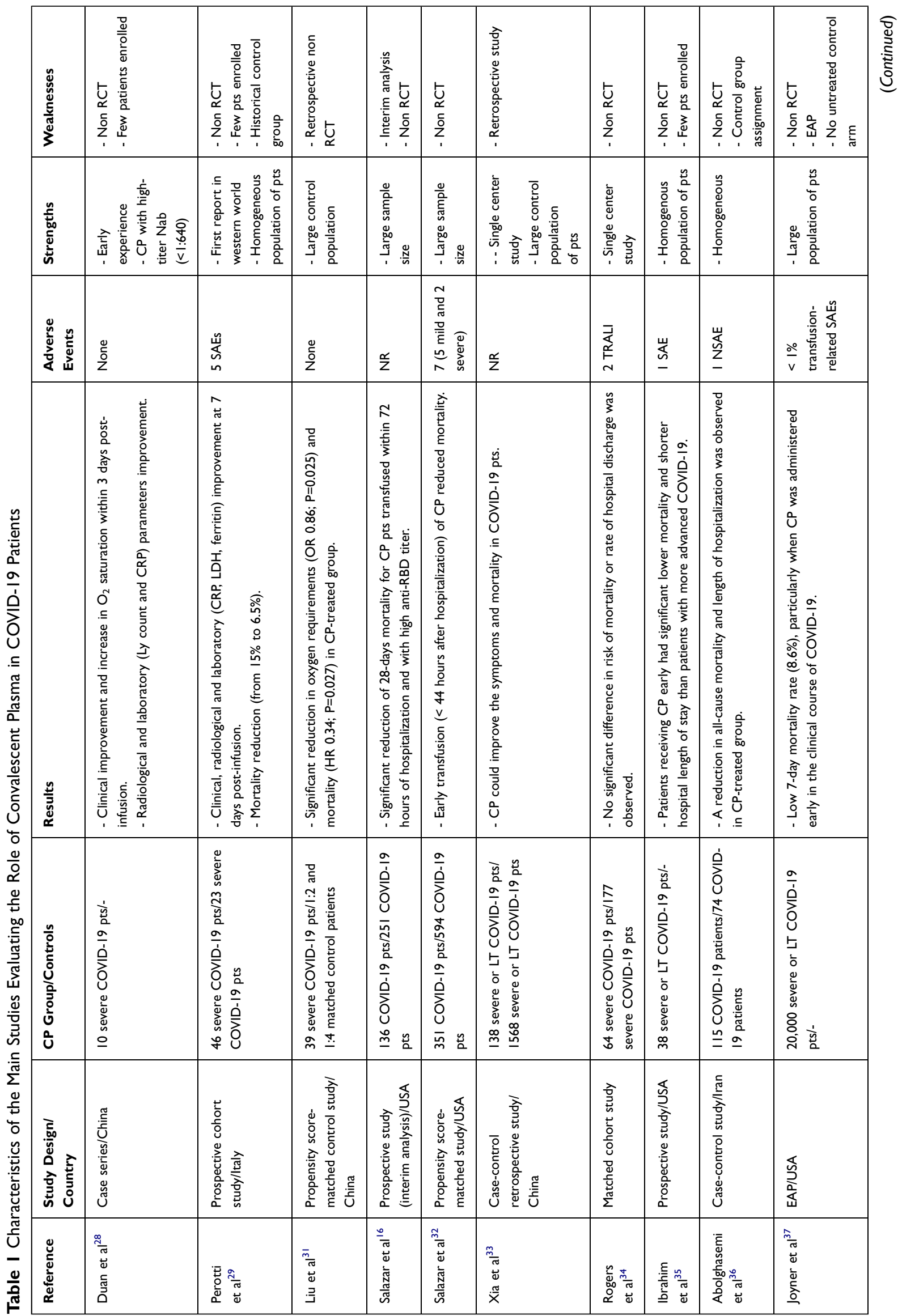




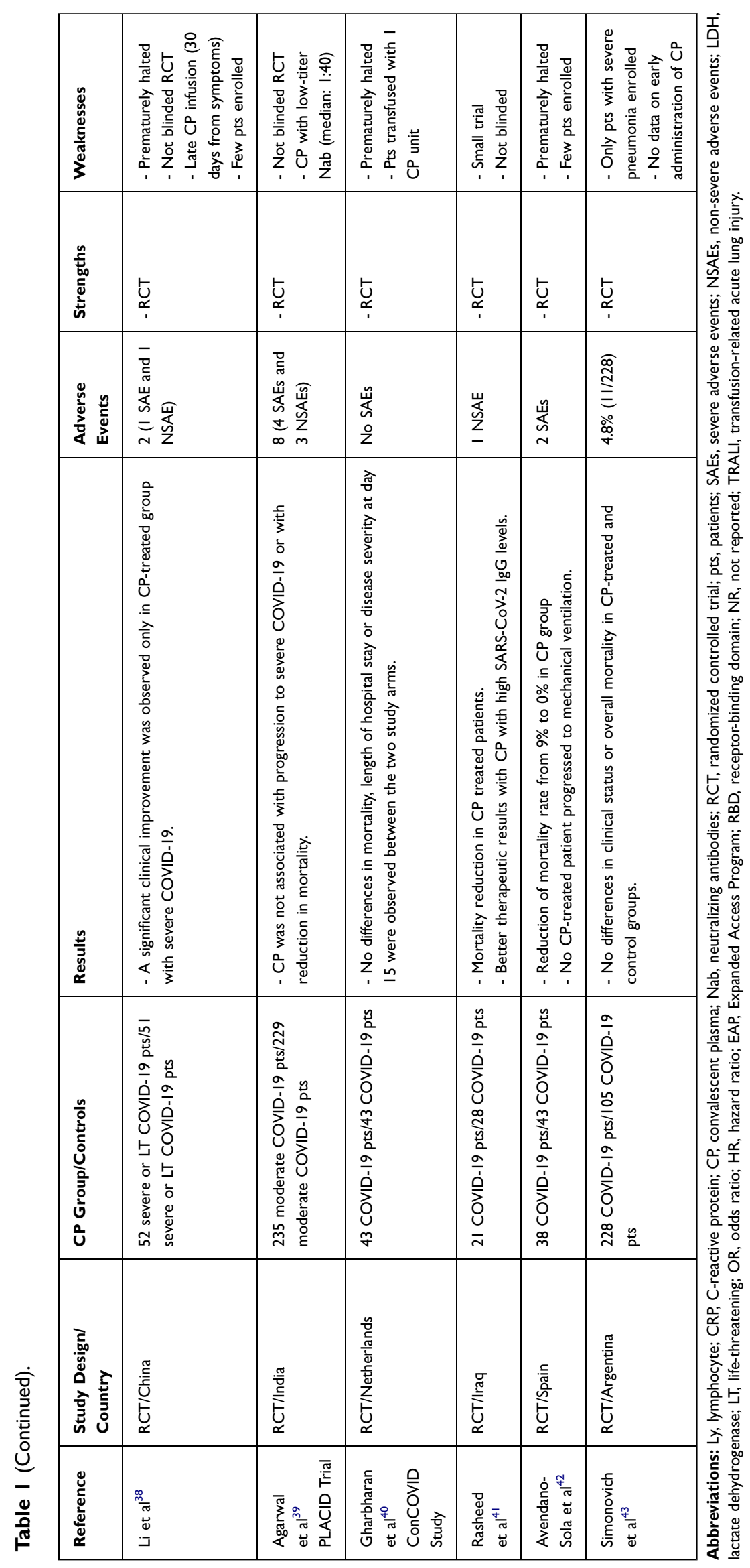


In a retrospective, propensity score-matched control study, Liu and colleagues assessed the efficacy of $\mathrm{CP}$ in severe COVID-19 patients. $^{31}$ A significant reduction in oxygen requirements (adjusted odds ratio $[\mathrm{OR}] 0.86 ; \mathrm{P}=0.025$ ) and a survival improvement (adjusted hazard ratio [HR] 0.34; $\mathrm{P}=0.027$ ) were observed in $\mathrm{CP}$-treated patients versus controls.

In the interim analysis of the prospective study conducted by Salazar and colleagues on 136 COVID-19 CP-treated patients and 251 controls, ${ }^{16}$ a trend towards a benefit from CP was observed. Differences in mortality appeared to be larger among subgroups of patients who were transfused early (ie, within 72 hours of hospital admission) with hightiter CP (ie, anti-receptor binding domain [RBD] IgG titer $\geq 1: 1350$ ). These findings were successively confirmed by the same authors in a 60-day follow-up study conducted in the whole cohort of $351 \mathrm{CP}$ transfused patients (Table 1). ${ }^{32}$

Similar positive results were showed in the retrospective analysis by Xia and colleagues in patients with severe or critical COVID-19. ${ }^{33}$

No significant difference in the mortality risk or in the rate of hospital discharge was observed by Rogers and colleagues between a group of patients treated with CP and control patients, ${ }^{34}$ although there was a suggestion of improved outcome among elderly patients.

The importance of the early administration of CP emerged from an analysis of the results of a study by Ibrahim and colleagues in the USA: COVID-19 patients who received CP early in their disease course had a significantly lower inhospital mortality rate $(13 \%$ vs $55 \%, \mathrm{P}=0.02)$ and a shorter mean time spent in hospital (15.4 days versus 33 days, $\mathrm{P}<0.01$ ) than those receiving $\mathrm{CP}$ later in the disease progression. ${ }^{35}$ These results were replicated in an Iranian case-control study by Abolghasemi and colleagues. ${ }^{36}$

During the initial emergency period of the SARS-CoV-2 pandemic, the fastest method to obtain clinical results on $\mathrm{CP}$ use by investigators was that of performing retrospective exploratory analyses of patients given the treatment for compassionate use or in the frame of expanded access programs (EAPs). The largest EAP was that conducted by the US Food and Drug Administration (FDA) in collaboration with the Mayo Clinic, whose results have been published recently. ${ }^{37}$ This study analyzed the key safety metrics of 20,000 hospitalized patients with COVID-19 treated with CP. The incidence of serious adverse events related to $\mathrm{CP}$ transfusion was low (less than 1\%) and the 7-day mortality was $8.6 \%$, with greater beneficial clinical effects observed when $\mathrm{CP}$ was administered earlier in the clinical course of COVID-19.
To date, six RCT have been published on the use of CP in COVID-19. ${ }^{38-43}$

An RCT of 103 patients with severe, life-threatening COVID-19 in China documented clinical improvement in $51.9 \%$ of patients treated with CP and in $43.1 \%$ of patients who received standard treatment, which was not a statistically significant difference $(\mathrm{P}=0.26) .{ }^{38}$ However, the trial was halted early because of the decrease in the number of patients with COVID-19 in China during the study period, which could have contributed to the study being underpowered to detect clinically significant results. Nevertheless, restricting the analysis only to patients with severe COVID-19, the difference in the primary outcome (clinical improvement) reached statistical significance $(91.3 \%$ versus $68.2 \%, \mathrm{P}=0.03$ ).

In the PLACID RCT carried out in India, 464 patients with moderate COVID-19 were randomized to receive CP or the best standard of care. After the analysis of the results, the authors concluded that CP was not associated with a reduction in mortality or progression to severe COVID$19 .^{39}$ Notably, three deaths possibly related to CP infusion were recorded. The main limitation of this study was the utilization of CP units with a low neutralizing antibody titer (median: 1:40).

An open-label RCT of CP versus standard of care, named the ConCOVID study, was conducted in the Netherlands. ${ }^{40}$ The trial was halted prematurely, when the baseline SARSCoV-2 neutralizing antibody titers of participants and $\mathrm{CP}$ units transfused were found to be comparable, challenging the potential benefit of $\mathrm{CP}$ in the patients included in this study. In any case, no differences in mortality $(\mathrm{P}=0.95)$, time spent in hospital $(\mathrm{P}=0.68)$ or disease severity at day $15(\mathrm{P}=0.58)$ were observed between the study arms.

A small RCT performed by Rasheed and colleagues on 21 COVID-19 patients treated with CP and 28 controls showed a reduction in mortality rate in $\mathrm{CP}$-treated group $(1 / 21$ versus $8 / 28, \mathrm{P}=0.03) .^{41}$

A Spanish RCT trial showed a reduction in mortality rate in CP-treated patients compared to controls. ${ }^{42}$ Of note, no CP-treated patient progressed to mechanical ventilation. However, this study, too, was halted prematurely because of the fall in recruitment related to control of the pandemic.

Finally, a randomized RCT from Argentina enrolling 333 patients with severe COVID-19 (228 treated with CP and 105 controls) observed no significant differences in clinical status or overall mortality between patients receiving $\mathrm{CP}$ and those who received placebo. ${ }^{43}$

All in all, the great majority of the studies selected on the basis of the number of patients enrolled and study 
Table 2 Main Characteristics of the Systematic Reviews and Meta-Analyses on the Role of Convalescent Plasma in COVID-19 Patients

\begin{tabular}{|c|c|c|c|c|c|}
\hline Reference & $\begin{array}{l}\text { Date of } \\
\text { Acceptance }\end{array}$ & $\begin{array}{l}\text { Publication } \\
\text { Type }\end{array}$ & $\begin{array}{l}\text { Number/Type of } \\
\text { Studies Included }\end{array}$ & $\begin{array}{l}\text { Number } \\
\text { of Pts } \\
\text { Evaluated }\end{array}$ & Main Conclusions \\
\hline $\begin{array}{l}\text { Rajendran } \\
\text { et al }{ }^{44}\end{array}$ & 29 April 2020 & $\begin{array}{l}\text { Systematic } \\
\text { review }\end{array}$ & $\begin{array}{l}\text { 5/I PT, I PC, I NR, I } \\
\text { CR, I DS }\end{array}$ & 27 & $\begin{array}{l}\text { - Convalescent plasma had a beneficial effect on symptoms and may } \\
\text { reduce mortality } \\
\text { - Increase in NAbT and disappearance of SARS-CoV-2 RNA was } \\
\text { observed in almost all patients in CP therapy }\end{array}$ \\
\hline $\begin{array}{l}\text { Bakhtawar } \\
\text { et al }{ }^{45}\end{array}$ & 3 August 2020 & $\begin{array}{l}\text { Systematic } \\
\text { review }\end{array}$ & $\begin{array}{l}\text { I0/I RCT, I PS, I RS, } \\
2 \mathrm{CR}, 5 \mathrm{CS}\end{array}$ & 156 & $\begin{array}{l}\text { - CP therapy produces notable improvements in patients' clinical } \\
\text { symptoms and radiological and biochemical parameters associated with } \\
\text { COVID-19 }\end{array}$ \\
\hline $\begin{array}{l}\text { Sarkar } \\
\text { et al }{ }^{46}\end{array}$ & 4 August 2020 & $\begin{array}{l}\text { Systematic } \\
\text { review/meta- } \\
\text { analysis }\end{array}$ & 7/2 RCT, $5 \mathrm{CS}$ & 5444 & $\begin{array}{l}\text { - CP reduced mortality (OR } 0.44 ; 95 \% \mathrm{Cl} 0.25-0.77) \text {, increased viral } \\
\text { clearance }(\mathrm{OR} \text { II.29; } 95 \% \mathrm{Cl} 4.9-25.9) \text { and improved clinical symptoms } \\
\text { (OR 2.06; } 95 \% \mathrm{Cl} 0.8-4.9)\end{array}$ \\
\hline $\begin{array}{l}\text { Rabelo-da- } \\
\text { Ponte } \\
\text { et } \mathrm{al}^{47}\end{array}$ & 6 August 2020 & $\begin{array}{l}\text { Metadata } \\
\text { analysis }\end{array}$ & 9/NA & 149 & $\begin{array}{l}\text { - CP was associated with reduced viral loads (RR } 0.13 ; 95 \% \mathrm{Cl} \\
0.09-0.18 \text { ), C-reactive protein levels (ROM } 0.11 ; 95 \% \mathrm{Cl} 0.01-0.86 \text { ) and } \\
\text { clinical improvement (ROM } 0.53 ; 95 \% \mathrm{Cl} 0.36-0.79 \text { ) when compared to } \\
\text { baseline }\end{array}$ \\
\hline $\begin{array}{l}\text { Talaie } \\
\text { et } \mathrm{al}^{48}\end{array}$ & 7 August 2020 & $\begin{array}{l}\text { Systematic } \\
\text { review/meta- } \\
\text { analysis }\end{array}$ & 7/NA & NA & $\begin{array}{l}\text { - CP had significant beneficial effect on clinical improvement (RR } \\
1.41, ; 95 \% \mathrm{Cl} \text { I.0I-1.98) and on negative conversion rate (RR 2.68; } 95 \% \\
\mathrm{Cl} 1.71-4.20 \text { ) } \\
\text { - A trend towards reduced mortality (RR } 0.52 ; 95 \% \mathrm{Cl} 0.26-1.03 \text { ) was } \\
\text { observed }\end{array}$ \\
\hline $\begin{array}{l}\text { Wang } \\
\text { et } \mathrm{a}^{49}\end{array}$ & 14 August 2020 & $\begin{array}{l}\text { Systematic } \\
\text { review/meta- } \\
\text { analysis }\end{array}$ & $3 / N A$ & NA & $\begin{array}{l}\text { - CP significantly increased the viral nucleic acid negative conversion rate } \\
\text { (RR } 2.47 ; 95 \% \mathrm{Cl} \text { I.70-3.57) and tended to decrease mortality risk (RR } \\
0.65 ; 95 \% \mathrm{Cl} 0.42-1.02 \text { ) }\end{array}$ \\
\hline Juul et a ${ }^{50}$ & 14 August 2020 & $\begin{array}{l}\text { Systematic } \\
\text { review/meta- } \\
\text { analysis }\end{array}$ & $2 / 2 \mathrm{RCT}$ & 189 & $\begin{array}{l}\text { - No definitive evidence of a difference between CP versus standard care } \\
\text { on all-cause mortality (RR } 0.60 ; 95 \% \mathrm{Cl} 0.33-1.10 \text { ) }\end{array}$ \\
\hline $\begin{array}{l}\text { Klassen } \\
\text { et al }\end{array}$ & $\begin{array}{l}29 \text { October } 2020 \\
\text { (preprint) }\end{array}$ & $\begin{array}{l}\text { Systematic } \\
\text { review/meta- } \\
\text { analysis }\end{array}$ & $\begin{array}{l}38 / 5 \mathrm{RCT}, 13 \mathrm{MCS} \text {, } \\
20 \mathrm{CS} \text { or } \mathrm{CR}\end{array}$ & 10,436 & $\begin{array}{l}\text { - Aggregated-data analysis showed a } 51 \% \text { reduction in mortality rate in } \\
\text { patients transfused with CP compared to patients receiving standard } \\
\text { treatments (OR 0.49; } 95 \% \mathrm{Cl} 0.37-0.64)\end{array}$ \\
\hline Chai et $\mathrm{al}^{52}$ & 12 October 2020 & $\begin{array}{l}\text { Systematic } \\
\text { review/meta- } \\
\text { analysis }\end{array}$ & $\begin{array}{l}\text { 19/2 RCT, } 8 \\
\text { controlled NRS, } 9 \\
\text { non-controlled NRS }\end{array}$ & 36,081 & $\begin{array}{l}\text { - Uncertainty regarding the safety and efficacy of CP basing on the } \\
\text { available literature data. }\end{array}$ \\
\hline
\end{tabular}

Abbreviations: CP, convalescent plasma; PT, pilot study; PC, preliminary communication; NR, novel report; CR, case report; DS, descriptive study; NAbT, neutralizing antibody titer; RCT, randomized controlled trial; CS, cohort studies; Pts, patients; OR, odds ratio; NA, not available; RR, risk ratio; ROM, ratio of mean; PS, prospective study; RS, retrospective study; MCS, matched-control studies; NRS, non-randomized studies.

design $(12 / 16,75 \%)$ showed a beneficial effect of CP treatment in severe COVID-19 patients in terms of clinical improvement and/or reduction of mortality risk. The high rate of biases (ie, small patient populations and study design) of these studies, including the RCTs, should, however, be highlighted.

\section{Systematic Reviews}

Several systematic reviews and meta-analyses on the use of $\mathrm{CP}$ in COVID-19 patients have already been published. However, given the continuing output of trials being published over time, ${ }^{44-52}$ the number of studies they include varies greatly according to the date of publication. Table 2 reports the main characteristics and conclusions of these systematic reviews according to the date of acceptance of the review.

The largest and most recent systematic review is the one pre-published by Klassen and colleagues. ${ }^{51}$ The authors identified a total of 38 studies including 5 RCTs, 13 matched-control studies and 20 case series or case reports for a total of 10,436 CODIV-19 patients. A pooled analysis of the outcome data showed a $51 \%$ reduction in mortality rate in patients transfused with $\mathrm{CP}$ compared to the rate in patients receiving standard treatments (OR 0.49; 95\% CI 0.37-0.64). ${ }^{51}$ 
In addition to these reviews, some investigators, considering the rapidly evolving scenario, have performed periodically updated systematic literature assessments, named living systematic reviews and meta-analyses. ${ }^{50,52}$ The second living update of the Cochrane Systematic Review included 19 studies (2 RCTs and 17 nonrandomized studies) evaluating 36,081 patients receiving $\mathrm{CP}^{52}$ On the basis of the available data, the authors were unable to reach a conclusion on the safety and efficacy of CP treatment for COVID-19. However, they were optimistic regarding the achievement of conclusive information in a future update, considering the huge number of ongoing studies (138, of which 73 are RCTs). ${ }^{52}$

\section{Conclusions}

COVID-19 is the largest global public health crisis of the 21st century. Due to the non-availability of specific vaccines, at the moment, synthetic drugs and biologic therapies (ie, CP, hyperimmune immunoglobulin and monoclonal antibodies) are the only weapons with which to tackle the virus. Among the latter treatments, only $\mathrm{CP}$ is currently available. Although not conclusive, there is accumulating evidence indicating that $\mathrm{CP}$ is safe and effective in blocking the progression of COVID-19 and obtaining clinical improvement, when administered early in the course of the disease and when containing an adequate titer of neutralizing antibodies. The results of the many ongoing RCTs will shortly help us to definitively assess the role played by $\mathrm{CP}$ in the management of COVID-19 patients.

\section{Disclosure}

The authors report no potential conflicts of interest regarding this work.

\section{References}

1. Schoeman D, Fielding BC. Coronavirus envelope protein: current knowledge. Virol J. 2019;16:69.

2. Chen Y, Liu Q, Guo D. Coronaviruses: genome structure, replication, and pathogenesis. J Med Virol. 2020;92:418-423. doi:10.1002/ jmv.25681

3. Kuiken T, Fouchier RA, Schutten M, et al. Newly discovered coronavirus as the primary cause of severe acute respiratory syndrome. Lancet. ～2003;362(9380):263-270. doi:10.1016/S0140-6736(03) 13967-0

4. Drosten C, Günther S, Preiser W, et al. Identification of a novel coronavirus in patients with severe acute respiratory syndrome. N Engl J Med. 2003;348(20):1967-1976. doi:10.1056/NEJMoa030747

5. de Groot RJ, Baker SC, Baric RS, et al. Commentary: middle east respiratory syndrome coronavirus (MERS-CoV): announcement of the Coronavirus Study Group. J Virol. 2013;87(14):7790-7792. doi:10.1128/JVI.01244-13
6. World Health Organization. Coronavirus disease (COVID-19) pandemic. Available from: https:/www.who.int/emergencies/dis eases/novel-coronavirus-2019. Accessed November 10, 2020.

7. Mahase E. Covid-19: WHO declares pandemic because of "alarming levels" of spread, severity, and inaction. BMJ. 2020;368:m1036. doi:10.1136/bmj.m1036

8. Lyngbakken MN, Berdal JE, Eskesen A, et al. A pragmatic randomized controlled trial reports lack of efficacy of hydroxychloroquine on coronavirus disease 2019 viral kinetics. Nat Commun. 2020;11 (1):5284. doi:10.1038/s41467-020-19056-6

9. Wang Y, Zhang D, Du G, et al. Remdesivir in adults with severe COVID-19: a randomised, double-blind, placebo-controlled, multicentre trial. Lancet. 2020;395(10236):1569-1578. doi:10.1016/ S0140-6736(20)31022-9

10. WHO Solidarity trial consortium. Repurposed antiviral drugs for COVID-19 -interim WHO SOLIDARITY trial results. medRxiv. 2020. doi:10.1101/2020.10.15.20209817

11. Shen C, Wang Z, Zhao F, et al. Treatment of 5 critically ill patients with COVID-19 with convalescent plasma. JAMA. 2020;323 (16):1582-1589. doi:10.1001/jama.2020.4783

12. Casadevall A, Dadachova E, Pirofski L. Passive antibody therapy for infectious diseases. Nat Microbiol Rev. 2004;2:695-703. doi:10.1038/ nrmicro974

13. Luke TC, Casadevall A, Watowich SJ, Hoffman SL, Beigel JH, Burgess TH. Hark back: passive immunotherapy for influenza and other serious infections. Crit Care Med. 2010;38:e66-e73. doi:10.1097/CCM.0b013e3181d44c1e

14. Luke TC, Kilbane EM, Jackson JL, Hoffman SL. Meta-analysis: convalescent blood products for Spanish influenza pneumonia: a future H5N1 treatment? Ann Intern Med. 2006;145:599-609. doi:10.7326/0003-4819-145-8-200610170-00139

15. Mair-Jenkins J, Saavedra-Campos M, Baillie JK, et al. The effectiveness of convalescent plasma and hyperimmune immunoglobulin for the treatment of severe acute respiratory infections of viral etiology: a systematic review and exploratory meta-analysis. J Infect Dis. 2015;211:80-90. doi:10.1093/infdis/jiu396

16. Salazar E, Christensen PA, Graviss EA, et al. Treatment of Coronavirus disease 2019 patients with convalescent plasma reveals a signal of significantly decreased mortality. Am J Pathol. 2020;190 (11):2290-2303. doi:10.1016/j.ajpath.2020.08.001

17. Wooding DJ, Bach H. Treatment of COVID-19 with convalescent plasma: lessons from past coronavirus outbreaks. Clin Microbiol Infect. 2020;26(10):1436-1446. doi:10.1016/j.cmi.2020.08.005

18. Stevens RW, Rivera CG, Saleh OA. Time to treat: applying lessons learned from other viral syndromes to SARS-CoV-2. Mayo Clin Proc Innov Qual Outcomes. 2020;4:759-763. doi:10.1016/j. mayocpiqo.2020.09.010.

19. Rojas M, Rodríguez Y, Monsalve DM, et al. Convalescent plasma in Covid-19: possible mechanisms of action. Autoimmun Rev. 2020;19 (7):102554. doi:10.1016/j.autrev.2020.102554

20. Mekonnen D, Mengist HM, Derbie A, et al. Diagnostic accuracy of serological tests and kinetics of severe acute respiratory syndrome coronavirus 2 antibody: a systematic review and meta-analysis. Rev Med Virol. 2020;5:e2181. doi:10.1002/rmv.2181.

21. Mazzini L, Martinuzzi D, Hyseni I, et al. Comparative analyses of SARS-CoV-2 binding (IgG, IgM, IgA) and neutralizing antibodies from human serum samples. J Immunol Methods. 2020;27:112937.

22. Padoan A, Bonfante F, Pagliari M, et al. Analytical and clinical performances of five immunoassays for the detection of SARS-CoV-2 antibodies in comparison with neutralization activity. EbioMedicine. 2020;62:103101. doi:10.1016/j.ebiom.2020.103101

23. Bal A, Pozzetto B, Trabaud M-A, et al. Evaluation of high-throughput SARS-CoV-2 serological assays in a longitudinal cohort of mild COVID-19 patients: sensitivity, specificity and association with virus neutralization test. medRxiv. 2020. doi:10.1101/ 2020.09.30.20194290 
24. Hoiland RL, Fergusson NA, Mitra AR, et al. The association of ABO blood group with indices of disease severity and multiorgan dysfunction in COVID-19. Blood Adv. 2020;4(20):4981-4989. doi:10.1182/ bloodadvances. 2020002623

25. Barnkob MB, Pottegård $\mathrm{A}$, Støvring $\mathrm{H}$, et al. Reduced prevalence of SARS-CoV-2 infection in ABO blood group O. Blood Adv. 2020;4 (20):4990-4993. doi:10.1182/bloodadvances.2020002657

26. Golinelli D, Boetto E, Maietti E, Fantini MP, Suppiah V. The association between ABO blood group and SARS-CoV-2 infection: a meta-analysis. PLoS One. 2020;15(9):e0239508. doi:10.1371/journal.pone.0239508

27. Franchini M, Glingani C, Del Fante C, et al. The protective effect of O blood type against SARS-CoV-2 infection. Vox Sang. 2020. doi:10.1111/vox.13003

28. Duan K, Liu B, Li C, et al. Effectiveness of convalescent plasma therapy in severe COVID-19 patients. Proc Natl Acad Sci U S A. 2020;117(17):9490-9496. doi:10.1073/pnas.2004168117

29. Perotti C, Baldanti F, Bruno R, et al. Covid-19 plasma task force. Mortality reduction in 46 severe COVID-19 patients treated with hyperimmune plasma. A proof of concept single arm multicenter trial. Haematologica. 2020;105:2834-2840. doi:10.3324/haematol.2020.261784

30. Franchini M. Why should we use convalescent plasma for COVID-19? Eur J Intern Med. 2020;77:150-151. doi:10.1016/j. ejim.2020.05.019

31. Liu STH, Lin HM, Baine I, et al. Convalescent plasma treatment of severe COVID-19: a propensity score-matched control study. Nat Med. 2020;26:1708-1713. doi:10.1038/s41591-020-1088-9.

32. Salazar E, Christensen PA, Graviss EA, et al. Significantly decreased mortality in a large cohort of coronavirus disease 2019 (COVID-19) patients transfused early with convalescent plasma containing high-titer anti-severe acute respiratory syndrome Coronavirus 2 (SARS-CoV-2) spike protein IgG. Am J Pathol. 2021;191 (1):90-107. doi:10.1016/j.ajpath.2020.10.008

33. Xia X, Li K, Wu L, et al. Improved clinical symptoms and mortality among patients with severe or critical COVID-19 after convalescent plasma transfusion. Blood. 2020;136(6):755-759. doi:10.1182/ blood.2020007079

34. Rogers R, Shehadeh F, Mylona EK, et al. Convalescent plasma for patients with severe COVID-19: a matched cohort study. Clin Infect Dis. 2020; ciaa1548. Doi:10.1093/cid/ciaa1548

35. Ibrahim D, Dulipsingh L, Zapatka L, et al. Factors associated with good patient outcomes following convalescent plasma in COVID-19: a prospective Phase II clinical trial. Infect Dis Ther. 2020;20:1-14.

36. Abolghasemi H, Eshghi P, Cheraghali AM, et al. Clinical efficacy of convalescent plasma for treatment of COVID-19 infections: results of a multicenter clinical study. Transfus Apher Sci. 2020;59:102875. doi:10.1016/j.transci.2020.102875

37. Joyner MJ, Bruno KA, Klassen SA, et al. Safety update: COVID-19 convalescent plasma in 20,000 hospitalized patients. Mayo Clin Proc. 2020;95(9):1888-1897. doi:10.1016/j.mayocp.2020.06.028

38. Li L, Zhang W, Hu Y, et al. Effect of convalescent plasma therapy on time to clinical improvement in patients with severe and life-threatening COVID-19: a randomized clinical trial. JAMA. 2020;324(5):460-470. doi:10.1001/jama.2020.10044

Biologics: Targets and Therapy

\section{Publish your work in this journal}

Biologics: Targets and Therapy is an international, peer-reviewed journal focusing on the patho-physiological rationale for and clinical application of Biologic agents in the management of autoimmune diseases, cancers or other pathologies where a molecular target can be identified. This journal is indexed on PubMed Central, CAS, EMBase,
39. Agarwal A, Mukherjee A, Kumar G, Chatterjee P, Bhatnagar T, Malhotra P; PLACID Trial Collaborators. Convalescent plasma in the management of moderate covid-19 in adults in India: open label phase II multicentre randomised controlled trial (PLACID Trial). BMJ. 2020;371:m3939. doi:10.1136/bmj.m3939

40. Gharbharan A, Jordans CCE, Geurtsvankessel C, et al. Convalescent plasma for COVID-19. A randomized trial. medRxiv. 2020

41. Rasheed AM, Fatak DF, Hashim HA, et al. The therapeutic potential of convalescent plasma therapy on treating critically-ill COVID-19 patients residing in respiratory care units in hospitals in Baghdad, Iraq. Infez Med. 2020;28(3):357-366.

42. Avendano-Sola C, Ramos-Martinez A, Munez-Rubio E, et al. Convalescent plasma for COVID-19: a multicenter, randomized clinical trial. medRxiv. 2020.

43. Simonovich VA, Burgos Pratx LD, Scibona P, et al. PlasmAr Study Group. A randomized trial of convalescent plasma in Covid-19 severe pneumonia. $N$ Engl $J$ Med. 2020. doi:10.1056/ NEJMoa2031304

44. Rajendran K, Krishnasamy N, Rangarajan J, Rathinam J, Natarajan M, Ramachandran A. Convalescent plasma transfusion for the treatment of COVID-19: systematic review. J Med Virol. 2020;92:1475-1483. doi:10.1002/jmv.25961

45. Bakhtawar N, Usman M, Khan MMU. Convalescent plasma therapy and its effects on COVID-19 patient outcomes: a systematic review of current literature. Cureus. 2020;12(8):e9535.

46. Sarkar S, Soni KD, Khanna P. Convalescent plasma is a clutch at straws in COVID-19 management! A systematic review and meta-analysis. J Med Virol. 2020.

47. Rabelo-da-Ponte FD, Silvello D, Scherer JN, Ayala AR, Klamt F. Convalescent plasma therapy in patients with severe or life-threatening COVID-19: a metadata analysis. J Infect Dis. 2020;222(9):1575-1578. doi:10.1093/infdis/jiaa509

48. Talaie H, Hosseini SM, Nazari M, et al. Is there any potential management against COVID-19? A systematic review and meta-analysis. Daru. 2020;28:1-13. doi:10.1007/s40199-020-00367-4.

49. Wang $\mathrm{M}, \mathrm{Wu} \mathrm{T}, \mathrm{Zuo} \mathrm{Z}$, et al. Evaluation of current medical approaches for COVID-19: a systematic review and meta-analysis. BMJ Support Palliat Care. 2020;bmjspcare-2020-002554. Doi:10.1136/bmjspcare-2020-002554.

50. Juul S, Nielsen EE, Feinberg J, et al. Interventions for treatment of COVID-19: a living systematic review with meta-analyses and trial sequential analyses (The LIVING Project). PLoS Med. 2020;17(9): e1003293. doi:10.1371/journal.pmed.1003293

51. Klassen SA, Senefeld JW, Johnson PW, et al. Evidence favoring the efficacy of convalescent plasma for COVID-19 therapy. medRxiv. 2020. doi:10.1101/2020.07.29.20162917.

52. Chai KL, Valk SJ, Piechotta V, et al. Convalescent plasma or hyperimmune immunoglobulin for people with COVID-19: a living systematic review. Cochrane Database Syst Rev. 2020;10:CD013600. doi:10.1002/14651858.CD013600.pub3
Scopus and the Elsevier Bibliographic databases. The manuscript management system is completely online and includes a very quick and fair peer-review system, which is all easy to use. Visit $\mathrm{http}: / /$ www.dovepress.com/testimonials.php to read real quotes from published authors. 